Assist. Prof. Dr. Mustafa ERSOY ${ }^{1}$

Sivas Cumhuriyet University, Turkey

Orhan KAVAKLIOGLU ${ }^{2}$

English Language Teacher at Ministry of National Education

Turkey
Original scientific paper

UDC: 37.022

DOI: $10.5937 /$ IstrPed2002324E

\title{
ATTITUDES OF TURKISH SECONDARY SCHOOL TEACHERS TOWARDS TECHNOLOGY ${ }^{3}$
}

\begin{abstract}
This study aims to evaluate secondary school teachers' attitudes towards technology in terms of various variables. The study attempts to reveal attitudes of teachers towards technology and influence of some variables like gender, self-efficacy, branch, in-service training and the level of education. Technology is becoming more widespread and important in education. The Ministry of National Education (MEB) started the Movement to Increase Opportunities and Technology (FATIH) project. FATIH project is one of the most comprehensive projects developed around the world in order to benefit from technological developments and to have a contemporary human resource. When the studies done in the field of education and technology are examined, it can be seen that they are generally focused on adaptation of technology and students' perspectives. However, a change without teachers is not possible even with technological developments. Thus, attitudes and approaches of secondary school teachers towards technology are gaining importance since students see teachers as their role models in their most critical period of development. For this reason, it is important to evaluate secondary school teachers' attitudes towards technology in terms of some variables. In this study, the general survey model was used. The population of the study was secondary school teachers working in Sivas during the 2017-2018 academic year. The sample of the study consisted of 200 secondary school teachers and they were selected randomly. In this study, the Scale for Pre-Service Teachers' Attitudes towards Technology, developed by Aydın and Karaa (2013) and consisting of 17 items, and Personal Information Form (PIF), developed by the researcher himself by consulting expert opinions, have been used to collect data. SPSS 25 package program has been used in the analysis of the data. Arithmetic mean, t-test and ANOVA analysis methods have been carried out in the analysis of the data.
\end{abstract}

Key Words: Technology, Secondary School Teachers, Attitude toward Technology.

${ }^{1}$ mstfrsy@gmail.com

2okavakloglu@gmail.com

${ }^{3}$ This study was orally presented at 4th International Congress on Education, Distance Education and Educational Technology- ICDET 23-24 November 2018 Antalya- Turkey 


\section{INTRODUCTION}

Technology has reached its golden age in the $21^{\text {st }}$ century is as it has a serious impact on changing the world. Therefore, societies and individuals are making great efforts in many areas in order to adapt to innovations brought by technology. In this vein, benefiting from and leading developments in the field of technology can be possible by making social and individual changes in the process that arises from the combination of education and technology, in which access to information differs and needs of modern education arise.

The integration of technology, which is based on the principle of making life easier, into education provides advantages in all stages of educational process. Providing multiple learning environments, meeting individual needs, increasing interest in the course (Yalin, 2003: 82-83), prevention of time loss, facilitating the achievement of objectives, making the course more interesting and providing permanent learning (Katranci \& Uygun, 2013: 773) are among the advantages of integrating technology into education.

Today, technological products used in almost every field have necessitated the integration of technology into learning environments. Considering Turkey, technological changes in the field of education have begun with overhead projections, then, projections have taken its place. Recently, with the establishment of FATIH Project, interactive and smart whiteboards have since been introduced. This process reveals the importance and necessity of using technology in teaching and learning environments (Bozkurt \& Cilvadaroglu, 2011; Riddell \& Song, 2012; Cakir \& Oktay, 2013; Gunuc \& Kuzu, 2014). The Ministry of National Education (MEB) has implemented the Movement to Increase Opportunities and Technology (FATIH) project, which is one of the most comprehensive projects developed around the world, to benefit from technological developments, to provide equal opportunities for all students, and to have a modern human resource that creates and develops information as a requirement of the information age. The aim of FATIH project is to provide equal opportunities for all students, to appeal to the senses by providing more effective use of information technology tools in learning and teaching processes in order to improve technology in schools, and to raise individuals who are capable of using technological products during their primary and secondary education periods.

Teachers, as in all areas of education, form the most important unit when integrating technology into classrooms. Beyond classrooms in which classical approaches are used, teachers are not only responsible for conveying the knowledge but also following learning processes of their students closely, reflecting their learning processes, and raising individuals who are able to keep up with the innovations and developments brought about by the era. Thus, besides being able to use technology effectively in educational environments, teachers should constantly increase their professional developments by using technology in their own development processes (Erdemir et al., 2010). As technology alone is not sufficient to integrate itself into the educational context, it is clear that an effective teaching process will be ensured when technology is used in an integrated manner with teaching contents (Koehler \& Mishra, 2005).

Teachers' perspectives on technology are important for them to use it effectively and efficiently in their classes (Celik \& Kahyaoglu, 2007: 573). Therefore, in order to benefit from technology, teachers are firstly supposed to adopt it, follow the developments closely and have a positive attitude towards technology (Sahin \& Akcay, 2011: 910). In this vein, Kiyici, 
Kahraman and Abali (2012) state that individuals' attitudes towards technology and their opinions on technology are some of the most important factors in efficiently using technology in the classroom.

Related literature on education and technology reveals that studies mostly focus on the adaptation of technology and students' perspectives. However, as aforementioned, an improvement without teachers is not possible even with technological developments. It is a requirement that teachers should be competent and effective in the field of technology. (Ozer \& Gelen, 2008). Although teachers emphasize the importance of using technology, it is clear that they do not integrate technology into the activities they prepare for their classrooms (Yakin \& Okur, 2018). Therefore, feelings, thoughts and believes of teachers who can directly influence all variables of the educational process gain importance. Moreover, teachers, who are the milestones of teaching and learning processes, should adapt themselves to the developments and changes in technology to meet the needs of students of the information age (Erten, 2019).

It is emphasized that although teachers have made great efforts in using technology in their classes, they still have to make efforts since technology evolves everyday (Nordlof, Hallstrom \& Host, 2019). As teachers' attitudes are considered a basic factor effecting the educational processes (Korur et al., 2016), studies on teachers' attitudes towards technology appear to be insufficient for a wider understanding and application of technology use in education. (Kurtoglu \& Seferoglu, 2013).

The aim of this study is to determine attitudes of secondary school teachers towards technology and examine these values in terms of gender, branch, level of education, in-service training and self-efficancy in technology.

In this vein, answers to following following questions are sought.

1. Is there a meaningful difference between secondary school teachers' genders and their attitudes towards technology?

2.Is there a meaningful difference between secondary school teachers' branches and their attitudes towards technology?

3.Is there a meaningful difference between secondary school teachers' level of education and their attitudes towards technology?

4. Is there a meaningful difference between secondary school teachers' self-efficacy levels in technology and their attitudes towards technology?

5.Is there a meaningful difference between secondary school teachers who received in-service training on technology and those who did not, and their attitudes towards technology?

\section{METHOD}

\section{Research Design}

In this study, the general survey model was used to determine attitudes of secondary school teachers towards technology. The general survey model is the research approach based on a group of samples taken from a larger sample (Karasar, 2012). In this approach, the sample is defined as it is without making any changes on the current situation. (Sonmez \& Alacapinar, 2016). Survey studies are studies in which opinions, interests, abilities and attitudes of participants are defined, especially when the sample is larger than other studies in terms of 
participants (Buyukozturk, Cakmak, Akgun, Karadeniz \& Demirel, 2009: 226). The general survey model is considered appropriate since this study aims to examine secondary school teachers' attitudes towards technology in terms of various variables

\section{Participants}

The participants $(\mathrm{N}=181)$ were secondary school teachers working in the city center of Sivas, and they were selected randomly. The participants of the study represented all thirteen different branches taught in the secondary schools. Initially, there were 200 participants, however, 19 of them were extracted due to incomplete or inaccurate filling. The distribution of the sample group according to variables is shown in Table 1.

Table 1. Distribution of Secondary School Teachers According to Variables

\begin{tabular}{|c|c|c|c|}
\hline Variables & & Frequency (f) & Persentage (\%) \\
\hline \multirow{3}{*}{ Gender } & Female & 92 & 50,8 \\
\hline & Male & 89 & 48,2 \\
\hline & Total & 181 & 100,0 \\
\hline \multirow{3}{*}{ In-service traing } & Yes & 102 & 56,4 \\
\hline & No & 79 & 43,6 \\
\hline & Total & 181 & 100,0 \\
\hline \multirow{3}{*}{ Level of Education } & Bachelors' Degree & 156 & 86,2 \\
\hline & Masters' Degree & 25 & 13,8 \\
\hline & Total & 181 & 100,0 \\
\hline \multirow{4}{*}{$\begin{array}{l}\text { Self-efficacy in } \\
\text { Technology }\end{array}$} & Yes & 64 & 35,4 \\
\hline & Partially & 102 & 56,4 \\
\hline & No & 15 & 8,2 \\
\hline & Total & 181 & 100,0 \\
\hline \multirow{14}{*}{ Branches } & Turkish & 28 & 15,5 \\
\hline & Mathematics & 29 & 16,0 \\
\hline & Science and Technology & 22 & 12,2 \\
\hline & Religious Culture and Moral Knowlege & 25 & 13,8 \\
\hline & English & 24 & 13,3 \\
\hline & Social Studies & 22 & 12,2 \\
\hline & Special Education & 4 & 2,2 \\
\hline & Music & 2 & 1,1 \\
\hline & Visual Arts & 9 & 5,0 \\
\hline & Technology and Design & 2 & 1,1 \\
\hline & Psychological Counseling and Guidance & 4 & 2,2 \\
\hline & Information Technologies & 5 & 2,8 \\
\hline & Physical Education & 5 & 2,8 \\
\hline & Total & 181 & 100,0 \\
\hline
\end{tabular}




\section{Data Collection Tool}

In this study, the Scale for Pre-Service Teachers' Attitudes towards Technology, developed by Aydin and Karaa (2013), and Personal Information Form (PIF), developed by the researcher, were used to collect data. The former was originally developed for the pre-service teachers, but the scale was used for teachers by consulting both the owners of the scale and other experts. The necessary permission was officially obtained. The 17-item scale was one dimension which consisted of 15 positive and 2 negative items. In this five-point Likert scale, negative items were scored in reverse.

The answers to each question were scored as "I disagree (1)", "I agree very little (2)", "I partially agree (3)", "I strongly agree (4)", "I totally agree (5)". Accordingly, the scale's score range was between 17 and 85 . The Cronbach's alpha reliability coefficient, which measures the scale reliability, was $a=0.87$, and this indicated that the scale had internal consistency reliability. In the personal information form developed by the researcher, there were questions regarding gender, level of education, self-efficacy in technology, in-service training, period of study and branch.

\section{Data Analysis}

The data obtained from the participants of the study were analyzed using SPSS 25.0 package program. The scores of teachers from the scale were collected and their attitude scores were defined. According to questions of the research, independent groups t-test was conducted to determine the effects of in-service training and gender variables on attitudes of teachers towards technology. In order to determine the effects of self-efficacy in technology and branch variables on attitudes of teachers towards technology, one-way ANOVA analysis of variance was conducted using a Tukey HSD Test as a post hoc test.

\section{FINDINGS}

In this study, the highest score that teachers can get from the scale, as it is aforementioned, is determined as 85 and the lowest score is 24 . The descriptive statistics of teachers according to scores of attitudes towards technology are as follows.

Table 2. Descriptive statistical values of teachers according to the attitude scale of technology

\begin{tabular}{cccccc}
\hline $\mathbf{N}$ & Min. & Max. & Mean & Med. & Mod \\
\hline 181 & 24 & 85 & 64.83 & 65 & 70 \\
\hline
\end{tabular}

According to Table 2, scores of teachers on the attitude scale showed normal distribution. Teachers received a minimum score of 24 and a maximum score of 85 from the attitude scale. In this case, the average score of teachers is " 64.83 ", which indicates that teachers' attitudes towards technology are at a good level.

\section{Findings with Regard to the First Research Question}

The first question of the research was determined as "Is there a meaningful difference between secondary school teachers' genders and their attitudes towards technology?". To answer this question, independent groups t-test was conducted. The results are shown in Table 3. 
Table 3. Independent groups t-test table based on the scores of teachers' attitude scale according to gender variable

\begin{tabular}{ccccccc}
\hline & N & Mean & Ss & t & df & p \\
\hline Female & 92 & 47,04 & 9,8 & - & 179 & .306 \\
Male & 89 & 48,66 & 11,3 & & & \\
\hline
\end{tabular}

Table 3 indicated that there was no significant difference between secondary school teachers' attitudes towards technology and gender variable. When the average scores were analyzed, the mean score of female teachers towards technology rendered a value of $(\bar{X}: 47,04)$, while the mean score of male teachers towards technology rendered a value of $(\bar{X}: 48,66)$. Although attitudes of male and female teachers towards technology varied, there was no significant difference between secondary school teachers' attitudes towards technology and gender variable.

\section{Findings with Regard to the Second Research Question}

The second question of the research was determined as "Is there a meaningful difference between secondary school teachers' branches and their attitudes towards technology?". Descriptive statistics for this question are given in table 4.

Table 4. Descriptive statistics on scores of teachers' attitude scale according to branch variable

\begin{tabular}{|c|c|c|c|}
\hline Branches & $N$ & Mean & $\begin{array}{l}\text { Std. } \\
\text { Deviation }\end{array}$ \\
\hline Turkish & 28 & 2,6471 & ,10693 \\
\hline Mathematics & 29 & 2,8905 & ,11997 \\
\hline Science and Technology & 22 & 3,0080 & ,12543 \\
\hline Social Studies & 25 & 2,8094 & ,11766 \\
\hline English & 24 & 2,9706 & 10015 \\
\hline $\begin{array}{c}\text { Religious Culture and Moral } \\
\text { Knowledge }\end{array}$ & 22 & 2,4171 & ,16328 \\
\hline Music & 4 & 3,1176 &, 32039 \\
\hline Technology and Design & 2 & 2,4412 & ,08824 \\
\hline Physical Education & 9 & 2,7647 & 19754 \\
\hline Visual Arts & 2 & 3,6176 & 14706, \\
\hline Information Technologies & 4 & 3,6471 & ,04803 \\
\hline $\begin{array}{l}\text { Psychological Counseling and } \\
\text { Guidance }\end{array}$ & 5 & 2,4000 & 16886 \\
\hline Special Education & 5 & 2,8941 & ,09558 \\
\hline Total & 181 & 2,8141 & ,04639 \\
\hline
\end{tabular}

Examining Table 4, there was no significant difference found between branches and average scores of teachers' attitudes towards technology. The highest average point was obtained by IT teachers with 3,64, while the lowest scores were obtained as 2.40 by Religious Culture and Moral Knowledge teachers, and 2,41 by Psychological Counselor teachers. As a result of the one-way ANOVA test to determine the differences between secondary school teachers' 
branches and their attitudes towards technology, it was observed that the variances were not distributed homogeneously. By taking the branch variable into consideration, one-way ANOVA test was repeated to cover 6 basic branches which consisted of 20 or more participants, including "Turkish", "Mathematics", "Science and Technology", "Social Studies", "English" and "Religious Culture and Moral Knowledge" teachers.

The table for the one-way ANOVA test is given below to see a significant difference between secondary school teachers' attitudes towards technology and their branches.

Table 5. One-way ANOVA test table on the scores of the teachers' attitude scale according to the branch variable

\begin{tabular}{lllllll}
\hline & Sum of Squares & Df & Mean of Squares & $\mathbf{F}$ & $\mathbf{p}$ & $\begin{array}{l}\text { Branches' } \\
\text { Differences (Tukey) }\end{array}$ \\
\hline Between- & 5,761 & 5 & 1,152 & 3,086 &, 011 & $3-6,5-6$ \\
\hline Within-group & 53,764 & 144 &, 373 & & & \\
\hline Total & 59,525 & 149 & & & \\
\hline
\end{tabular}

The ANOVA test results showed that there was a significant difference between scores of secondary school teachers on attitudes towards technology and their branches $(P<0.05)$. A Tukey test was conducted as a post hoc to see the differences between branches. It was determined that there were significant differences between "Science and Technology" and "Religious Culture and Moral Knowledge" teachers and "English" and "Religious Culture and Moral Knowledge" teachers.

Looking at average scores shown in Table 4, it is seen that the average score of "Religious Culture and Moral Knowledge" teachers $(\bar{X}: 2,4171)$ is lower than the average score of "Science and Technology" ( $\bar{X}: 3,0080)$ and "English" $(\bar{X}: 2,9706)$ teachers. Therefore, it can be stated that this difference is in favor of "Science and Technology" and "English" branches.

\section{Findings with Regard to the Third Research Question}

The third question of the research was determined as "Is there a meaningful difference between secondary school teachers' level of education and their attitudes towards technology?". To answer this question, independent groups t-test was applied. The findings are shown in Table 6.

Table 6. Independent groups t-test table on the scores of the teachers' attitude scale according to the level of education variable

\begin{tabular}{lcccccc}
\hline & N & Mean & Ss & t & df & p \\
\hline $\begin{array}{l}\text { Bachelor's } \\
\begin{array}{l}\text { Degree } \\
\text { Master's }\end{array}\end{array}$ & 156 & 64,20 & 9,80 & $-1,55$ & 27,73 & .132 \\
\begin{tabular}{l} 
Degree \\
\hline
\end{tabular} & 25 & 68,80 & 14,28 & & & \\
\hline
\end{tabular}

When Table 6 was analyzed, there was no significant difference between secondary school teachers' attitudes towards technology and their levels of education. When average scores are compared, the attitude point of teachers who hold bachelor's degrees was $(\bar{X}: 64.20)$, 
while the attitude score of teachers who hold master's degrees was ( $\bar{X}: 68.80)$. Although there were differences in attitude scores of secondary school teachers towards technology, the table indicated that there was no significant difference between secondary school teachers' attitudes towards technology and their levels of education.

\section{Findings with Regard to the Fourth Research Question}

The fourth question of the research was determined as "Is there a meaningful difference between secondary school teachers' self-efficacy levels in technology and their attitudes towards technology?". The descriptive statistical values of secondary school teachers' attitudes towards technology according to their levels of self-efficacy are as follows.

Table 7. Descriptive statistics related to scores of teachers on attitude scale according to self-efficacy levels in technology variable

\begin{tabular}{cccc}
\hline Self-efficacy in Technology & $\mathbf{N}$ & Mean & Std. Deviation \\
\hline Yes & 64 & 71,1719 & 9,1348 \\
\hline Partially & 102 & 62,7059 & 8,9537 \\
\hline No & 15 & 52,3333 & 10,4448 \\
\hline Total & 181 & 64,8398 & 10,6087 \\
\hline
\end{tabular}

According to Table 7, the average score of secondary school teachers who saw themselves adequately self-efficient in technology was $(\overline{\mathrm{X}}: 71,17)$. The average score of those who saw themselves partially self-efficient in technology was $(\bar{X}: 62.70)$, and the average score of those who saw themselves inefficient in technology was $(\bar{X}: 52,33)$.

The table for the one-way ANOVA test to determine whether there was a significant difference between the scores of secondary school teachers on the scale of attitudes towards technology and their scale of self-efficacy in technology is given Table 8 .

Table 8. One-way ANOVA test table on scores of teachers on attitude scale according to their scale of selfefficiancy in technology

\begin{tabular}{lllllll}
\hline & $\begin{array}{l}\text { Sum of } \\
\text { Squares }\end{array}$ & df & $\begin{array}{l}\text { Mean of } \\
\text { Squares }\end{array}$ & $\mathbf{F}$ & $\mathbf{p}$ & $\begin{array}{l}\text { Branches' Differences } \\
\text { (Tukey) }\end{array}$ \\
\hline Between-groups & 5376,734 & 2 & 2688,367 & 32,156 & ,000 & $1-2,1-3$ \\
\hline Within-group & 14881,619 & 178 & 83,605 & & & \\
\hline Total & 20258,354 & 180 & & & & \\
\hline
\end{tabular}

As shown in table 8, one-way ANOVA test results showed that there was a significant difference between secondary school teachers' level of self-efficacy in technology and their attitudes towards technology $(\mathrm{P}<0.05)$. According to the Tukey test, which was applied as a post hoc test to determine the differences among groups, it was concluded that there was a significant difference between the ones who saw themselves adequately self-efficient in technology and others who saw themselves partially self-efficient or inefficient. 
Looking at Table 7, it is seen that the average score of secondary school teachers who saw themselves adequately self-efficient in technology $(\bar{X}: 71,17)$ is higher than others who saw

themselves partially self-efficient $(\overline{\mathbf{X}}: 62,70)$ and inefficient $(\overline{\mathbf{X}}: 52,33)$. Therefore, it can be stated that this difference is in favor of secondary school teachers who saw themselves adequately self-efficient in technology.

\section{Findings with Regard to the Fifth Research Question}

The fifth question of the research was determined as "Is there a meaningful difference between secondary school teachers who received in-service training on technology and those who did not, and their attitudes towards technology?". To answer this question, independent groups t-test was applied. The findings are shown in Table 9.

Table 9. Independent groups t-test table based on teachers' attitude scale according to the variable of inservice training on technology

\begin{tabular}{ccccccc}
\hline Inservice Training & $\mathbf{N}$ & Mean & Ss & $\mathbf{t}$ & df & $\mathbf{p}$ \\
\hline Yes & 102 & 66,22 & 10,68 & 2,014 & 179 & .046 \\
No & 79 & 63,05 & 10,29 & & & \\
\hline
\end{tabular}

Examining Table 9, a significant difference could not be obtained between teachers who received in-service training on technology and those who did not. It was seen that the average score of secondary school teachers who received in-service training on technology was $(\overline{\mathbb{X}}$ : $66.22)$, while the average score of those who did not was ( $\overline{\bar{K}}: 63.05)$.

\section{CONCLUSION AND DISCUSSION}

This study was conducted to evaluate attitudes of secondary school teachers towards technology in terms of various variables. Variables were examined under five questions and it was observed that there were some similarities among attitudes of secondary school teachers towards technology in terms of gender, branches, level of education and in-service training variables.

There was no significant difference between secondary school teachers' attitudes towards technology and gender variable. Bush (1995), Celik and Bindak (2005), Kose and Gezer (2006), and Bakr (2011) could not obtain any significant difference in terms of gender, either. However, Saracaloglu, Uca and Candar (2012) stated that teachers' attitudes towards technologhy might differ not according to gender but according to the socio-economic conditions and the atmosphere in the schools. In addition, they concluded that the average score of male teachers' attitudes towards technology was higher than the average score of female teachers. Whitley (1997), Demirer and Dikmen (2016), Sahin and Arslan Namli (2019) stated that male students' attitudes were more positive than female students' in their study on stundets' attitudes towards computers. As it can be seen in a body of research, a significant difference according to gender of teachers could not be obtained (Torkzadeh, Pflughoeft \& Hall, 1999; Akkoyunlu \& Orhan, 2003; Kus, 2005; Seferoglu \& Akbiyik, 2005; Yilmaz et al., 2006; Arslan, 2008; Baki et al., 2008; Islahi \& Nasrin, 2019). 
There was no significant difference between secondary school teachers' attitudes towards technology and branch variables. Considering secondary school teachers' distribution according to branches, the differences in attitude points towards technology of six core curriculum courses (Turkish, Mathematics, Science and Technology, Social Studies, English and Religious Culture and Moral Knowledge), with 20 or more participants each, were examined. Among these six branches, a significant difference was found between "Science and Technology", "English" and "Religious Culture and Moral Knowledge" teachers. "Science and Technology" and "English" teachers attracted the most attention as they had the highest mean scores.

There was no significant difference between secondary school teachers' attitudes towards technology and level of education variables. Besides, it was cocluded that mean scores of teachers who hold master's degrees are higher than the ones who hold bachelor's degrees.

There was a significant difference between secondary school teachers' attitudes towards technology and self-efficacy in technolgy. As a result of this analysis, it was concluded that this difference was in favor of teachers who saw themselves adequately self-efficient in technology. Similarly, Abbitt (2011) found that it was essential for teachers to see themselves efficient in technology to make use of it in education effectively. It was seen that average scores of secondary school teachers who considered themselves partially self-efficient or inefficient were lower than scores of the ones who considered themselves adequately selfefficient in technology. Additionally, Gokbulut and Coklar (2018) stated that the teachers' psychological well-being and psychological capital levels helped them to be more effective and productive in their educational processes.

A significant difference between receiving in-service training on technology and attitudes towards technology could not be obtained. This finding conflicts with the previous resarch conducted on this subject. It was stated that receiving educational processes to use technology effectively in education had positive results (Corkett \& Benedives, 2015; Williams, 2017; Kozikoglu \& Babacan, 2019). While the average attitude score of the secondary school teachers who received in-service training on technology was $(\bar{X}: 66,22)$, the average score of those who did not was $(\bar{X}: 63,05)$.

To sum up, in terms of gender, branch, level of education and receiving in-service training variables, secondary school teachers' attitudes towards technology did not differ significantly. Attitudes of secondary school teachers towards technology vary according to self-efficacy in technology variable. In this study, it can be said that groups who had positive attitudes were male teachers for gender variable, "Science and Technology" and "English" teachers for branch variable and teachers who hold master's degrees for level of education variable. In similar studies, it was observed that teachers' attitudes towards technology were similar. As a result of these studies, it was revealed that there was a positive and high level of meaningful relationship between teachers' Information and Communication Technologies practise success points and attitude points towards information and communication technologies. A body of research stated that teachers' attitudes towards the integration of technology into education were positive (Hizal, 1989; Albirini, 2006; Gercek et al., 2006; Cure \& Ozdener, 2008; Cavas et al., 2009; Hichecoglu, 2015; Altun, Gulay \& Siyambas Mazlum, 2018). 
According to the results of the research, it is concluded that equal opportunities should be provided in terms of teacher education, teachers should be equipped and updated both professionally and technically, and teachers' perception of self-efficacy should be increased. It should be ensured that secondary school teachers, who conduct, direct, and guide students' first contacts with technology, should be self-efficant and competent in this area. For this reason, as in all stages of life, technology should be used actively and effectively from the very beginning of the education provided that the information about use of related equipment should be planned in a detailed and logical way.

\section{References}

Abbitt, J. T. (2011). An Investigation of The Relationship Between Self-Efficacy Beliefs about Technology Integration and Technological Pedagogical Content Knowledge (TPACK) Among Preservice Teachers. Journal of Digital Learning in Teacher Education, 27(4), 134143.

Akkoyunlu, B. \& Orhan, F. (2003). Bilgisayar ve Ogretim Teknolojileri Egitimi (Bote) Bolumu Ogretmen Adaylarının Bilgisayar Kullanma Oz Yeterlik Inanci ile Demografik Ozellikleri Arasindaki Iliski. The Turkish Online Journal of Educational Technology, 2(3), 86-93.

Albirini, A. (2006). Teachers Attitudes Toward Information and Communication Technologies: The Case Of Syrian Efl Teachers. Computers \& Education, 47, 373-398.

Altun, T., Gulay, A. \& Siyambas Mazlum, P. (2018). Ilk Defa Etkilesimli Tahta Kullanan Ogretmenlerin Algilarinin Incelenmesi. Abant Izzet Baysal Universitesi Egitim Fakultesi Dergisi, 18(2), 634-654.

Arslan, A. (2008). Ogretmen Adaylarinin Bilgisayar Destekli Egitim Yapmaya Yonelik Tutumlari ile Oz-Yeterlik Algilari Arasindaki Iliski. Elektronik Sosyal Bilimler Dergisi, 7(24), 101-109.

Aydin, F. \& Karaa, N. F. (2013). Ogretmen Adaylarinin Teknolojiye Yonelik Tutumlari: Olcek Gelistirme Calismasi." Turk Fen Egitimi Dergisi, 10(4), 103-118.

Baki, A., Kutluca, T. \& Birgin, O. (2008). Matematik Ogretmeni Adaylarinin Bilgisayar Destekli Egitime Yonelik Oz-Yeterlik Algilarinin Incelenmesi. VIII. International Educational Technology Conference Bildiriler Kitabi, 6-9 May, 77-81, Anadolu Universitesi, Eskisehir.

Bakr, S. M. (2011). Attitudes of Egyptian Teachers Towards Computers. Contemporary Educational Technology, 2(4), 308-318.

Bozkurt, A. \& Cilvadaroglu, A. K. (2011). Matematik ve Sinif Ogretmenlerinin Teknolojiyi Kullanma ve Derslerine Teknolojiyi Entegre Etme Algilari. Kastamonu Egitim Dergisi, 19(3), 859-870.

Bush, T. (1995). Gender Differences in Self Efficacy and Attitudes Toward Computers. Journal of Educational Computing Research, 12, 147-158.

Buyukozturk, S., Cakmak, E. K., Akgun, O. E., Karadeniz, S. \& Demirel, F. (2009). Bilimsel Arastirma Yontemleri. 3. Baski Ankara: Pegem Akademi.

Cakir, O., \& Oktay, S. (2013). Bilgi Toplumu Olma Yolunda Ogretmenlerin Teknoloji Kullanımlari. Gazi Universitesi Endustriyel Sanatlar Egitim Fakultesi Dergisi, 30, 35- 54.

Cavas, B., Cavas, P., Karaoglan, B. \& Kisla, T. (2009). A Study on Science Teachers' Attitudes Toward Information And Communication Technologies In Education. The Turkish Online Journal of Educational Technology - TOJET April 2009 ISSN: 1303-6521. 8 (2).

Celik, H. C., \& Bindak, R. (2005). Ilkogretim Okullarında Gorev Yapan Ogretmenlerin Bilgisayara Yonelik Tutumlarinin Cesitli Degiskenlere Gore İncelenmesi. Inonu U. Egitim Fakultesi Dergisi, 6(10), 27-38. 
Celik, H. C., \& Kahyaoglu, M. (2007). Ilkogretim Ogretmen Adaylarinin Teknolojiye Yonelik Tutumlarinin Kumeleme Analizi. Turk Egitim Bilimleri Dergisi, 5(4), 571-586.

Corkett, J. K. \& Benedives, T. (2015). Pre-Service Teachers' Perception of Technology and Multiliteracy within The Inclusive Classroom. International Journal of Psychology and Educational Studies, 2(2), 35-46.

Cure, F., \& Ozdener, N. (2008). Ogretmenlerin Bilgi ve Iletisim Teknolojileri (Bit) Uygulama Basarilari ve Bit'e Yonelik Tutumlari. Hacettepe Universitesi Egitim Fakultesi Dergisi, 34(34), 41-53.

Demirer, V., \& Dikmen, C. (2016). Ogretmenlerin Teknoloji Entegrasyonuna Yonelik Davranislarini Etkileyen Degiskenlerin Incelenmesi. İnonu Universitesi Egitim Fakultesi Dergisi, 17(3), 153-167.

Elcicek, Z. (2019). Ogretmen Adaylarinin Akilli Tahta Uygulamalarina Iliskin Tutumlarinin Incelenmesi. Elektronik Sosyal Bilimler Dergisi, 18(71), 1215-1221.

Erdemir, N., Bakirci, H., \& Eyduran, E. (2009). Ogretmen Adaylarinin Egitimde Teknolojiyi Kullanabilme Ozguvenlerinin Tespiti. Journal of Turkish Science Education, 6(3), 99-108.

Erten, P. (2019). Z Kusaginin Dijital Teknolojiye Yonelik Tutumlari." Gumushane Universitesi Sosyal Bilimler Enstitusu Elektronik Dergisi, 10(1), 190-202.

Gercek., C., Koseoglu. P., Yilmaz, M., \& Soran, H. (2006). Ogretmen Adaylarının Bilgisayar Kullanimina Yonelik Tutumlarinin Cesitli Degiskenler Acisindan Incelenmesi. H.U. Egitim Fakultesi Dergisi, (30)130-139.

Gokbulut, B., \& Coklar, A. N. (2018). Investigation of the Relationship between Teachers' Technology Use and Psychological Capital. Anadolu University Journal of Education Faculty, 2(4), 280-294.

Gunuc, S., \& Kuzu, A. (2014). Derste Teknoloji Kullanimina Yonelik Egilim Olcegi: Gelistirme, Guvenirlik ve Gecerlik. Egitimde Kuram ve Uygulama, 10(4), 863-884.

Hizal, A. (1989). Bilgisayar Egitimi ve BDO Iliskin Ogretmen Goruslerinin Degerlendirilmesi. Anadolu Universitesi Yayinlari. Eskisehir. http://portal.ted.org.tr/genel/yayinlar /Ogretmen_Yeterlik_Kitap.pdf)

Islahi, F., \& Nasrin (2019). Exploring Teacher Attitude towards Information Technology with a Gender Perspective. Contemporary Educational Technology, 10, 37-54.

Karasar, N. (2012). Bilimsel Arastirma Yontemi. Ankara: Nobel Yayin Dagitim

Katranci, M., \& Uygun, M. (2013). "Sinif Ogretmenlerinin Turkce Derslerinde Teknoloji Kullanimina Yonelik Gorusleri. Adıyaman Universitesi Sosyal Bilimler Enstitusu Dergisi Turkcenin Egitimi Ogretimi Ozel Sayisi, 6(11), 773-797.

Kiyici, G., Kahraman, N., \& Abali, Y. (2012). Kimyager Adaylarinin Teknoloji Tutumlarinin Kimya Tutumlarina Etkisinin Arastirilmasi. Egitim Teknolojileri Arastirmalari Dergisi, 3 (1).

Koehler, M. J., \& Mishra, P. (2005). What Happens When Teachers Design Educational Technology? The Development of Technological Pedagogical Content Knowledge. Journal of Educational Computing Research, 32(2), 131-152.

Korur, F., Vargas, R. V., \& Serrano, N. T. (2016). Attitude toward science teaching of Spanish and Turkish in-service elementary teachers: Multi-group confirmatory factor analysis. Eurasia Journal of Mathematics, Science \& Technology Education, 12(2), 303-320.

Kose, S., Gencer A. S., \& Gezer K. (2007). Meslek Yuksekokulu Ogrencilerinin Bilgisayar ve Internet Kullanimina Yonelik Tutumlari." Pamukkale Universitesi Egitim Fakultesi Dergisi, (1), 44-54.

Kozikoglu, I., \& Babacan, N. (2019). The investigation of the relationship between Turkish EFL teachers' technological pedagogical content knowledge skills and attitudes towards technology." Journal of Language and Linguistic Studies, 15(1), 20-33.

Kurtoglu, M., \& Seferoglu, S. (2013). Ogretmenlerin Teknoloji Kullanimi ile Ilgili Turkiye Kaynakli 
Dergilerde Yayimlanmis Makalelerin Incelenmesi. JITTE, 2(3), 1-10.

Kus, B. (2005). Ogretmenlerin Bilgisayar Oz-Yeterlik Inanclari ve Bilgisayar Destekli Ogretime Yonelik Tutumlari." Hacettepe Universitesi Fen Bilimleri Enstitusu Bilgisayar ve Ogretim Teknolojileri Egitimi, Ankara. Yayinlanmamis yuksek lisans tezi.

Nordlof, C., Hallstrom, J., \& Host, G.E. (2019). Self-efficacy or context dependency? Exploring teachers' perceptions of and attitudes towards technology education. Int J Technol Des Educ 29, 123-141.

Ozer, B., \& Gelen, I. (2008). Ogretmenlik Meslegi Genel Yeterliklerine Sahip Olma Duzeyleri Hakkinda Ogretmen Adaylari ve Ogretmenlerin Goruslerinin Degerlendirilmesi. Mustafa Kemal Universitesi Sosyal Bilimler Enstitusu Dergisi, 5(9), 39-55.

Riddell, W. C., \& Song, X. (2012). The role of education in technology use and adoption: Evidence from the canadian workplace and employee survey. IZA Discussion Paper No. 637, Institute for the Study of Labor.

Sahin, A., \& Akcay, A. (2011). Turkce Ogretmeni Adaylarinin Bilgisayar Destekli Egitime Iliskin Tutumlarinin Incelenmesi. Turkish Studies- International Periodical for The Languages, Literature and History of Turkish or Turkic, 6(2), 909-918.

Sahin, M., \& Arslan Namli, N. (2019). Ogretmen Adaylarinin Egitimde Teknoloji Kullanma Tutumlarinin Incelenmesi. Turkiye Sosyal Arastirmalar Dergisi, 23(1), 95-112.

Saracaloglu, A., Uca, S., \& Candar, M. (2012). Ogretmenlerin bilgisayar ozyeterlik inanclari, teknolojiye yonelik tutumlari, egitsel internet kullanim ozyeterlik inanclari ile bilgi teknolojilerini kullanma duzeylerinin karsilastirilmasi. Adnan Menderes Universitesi Egitim Fakultesi Egitim Bilimleri Dergisi, 3(1), 74-90.

Seferoglu, S., \& Akbiyik, C. (2005). Ilkogretim Ogretmenlerinin Bilgisayara Yonelik Oz-Yeterlik Algilari Uzerine Bir Calisma. Egitim Arastirmalari Dergisi, (19), 89-101.

Sonmez, V. \& Alacapinar, F. G. (2016). Orneklendirilmis Bilimsel Arastirma Yontemleri (Genisletilmis 4. Baski). Ankara: Ani Yayincilik.

Torkzadeh, R., Pflughoeft, K., \& Hall, L. (1999). Computer Self-Efficacy, Training Effectiveness and User Attitudes: An Empirical Study. Behavior \& Information Technology, 18(4): 299309.

Whitley, B. (1997). Gender Differences in Computer Related Attitudes and Behavior: A MetaAnalysis. Computers in Human Behavior, 13(1), 1-22.

Williams, M. E. (2017). Technology Integration Support Levels for In-Service Teachers. Journal of education and practice, 8(7), 76-81.

Yakin, I., \& Okur, S. (2018). Ortaokul Ogretmenlerinin Egitim Teknolojisi Standartlari Tanimlamalarina ve Gostergelerine Yonelik Gorusleri. Abant Izzet Baysal Universitesi Egitim Fakultesi Dergisi, 18(4), 2390-2407.

Yalin, H. I. (2003). Ogretim Teknolojileri ve Materyal Gelistirme. Ankara: Nobel Yayinlari.

Yilmaz, M., Koseoglu, P., Gercek, C., \& Soran H. (2006). Hacettepe Universitesi Biyoloji Ogretmen Adaylarinin Bilgisayarla Ilgili Ozyeterlik Inanclarinin Incelenmesi. Hacettepe Universitesi Egitim Fakultesi Dergisi, 30, 278-287.

\section{Biographical notes:}

Mustafa ERSOY, interested in Distance Education, Instructional Technologies, Digital course content development and artificial intelligence-based measurement and evaluation, has a Master's and Doctorate degrees in Education Programs and Instruction. He has been working as an Assistant Professor in Sivas Cumhuriyet University at the Department of Educational Sciences since 2006. 
Orhan KAVAKLIOĞLU, after completed his primary and secondary education in Sivas, he graduated from Erciyes University, Faculty of Education, Department of English Language Teaching in 2010. In the same year, he started to work as an English teacher under the Ministry of National Education. In 2017, he started his master's degree in Cumhuriyet University at the Institute of Educational Sciences. 